\title{
A taste for exotic food: Neotropical land planarians feeding on an invasive flatworm
}

Piter K Boll, Ilana Rossi, Silvana V Amaral, Ana Leal-Zanchet

Invasive species establish successfully in new habitats especially due to their ability to include new species in their diet and due to the freedom from natural enemies. However, native species may also adapt to the use of new elements in their ecosystem. The planarian Endeavouria septemlineata, first recorded in Hawaii, was later found in Brazil. Recently we found it in human-disturbed areas in southern Brazil and here we investigate its interactions with other invertebrates both in the field and in the laboratory. We observed the species in the field during collecting activities and hence maintained some specimens alive in small terraria in the laboratory, where we offered different invertebrate species as potential prey and also put them in contact with native land planarians in order to examine their interaction. Both in the field and in the laboratory, E. septemlineata showed a gregarious behavior and was found feeding on woodlice, millipedes, earwigs and gastropods. In the laboratory, specimens often did not attack live prey, but immediately approached dead specimens, indicating a scavenging behavior. In an experiment using the slug $D$. laeve and the woodlouse Atlantoscia floridana, there was a higher consumption of dead specimens of woodlice and slugs compared to live specimens, as well as a higher consumption of dead woodlice over dead slugs. Four native land planarians of the genus Obama and one of the genus Paraba attacked and consumed E. septemlineata, which, after the beginning of the attack, tried to escape by tumbling or using autotomy. As a scavenger, E. septemlineata would have no impact on the populations of species used as food, but could possibly exclude native scavengers by competition. On the other hand, its consumption by native land planarians may control its spread and thus reduce its impact on the ecosystem. 


\section{A taste for exotic food: Neotropical land planarians feeding on an invasive flatworm}

2

3 Piter K. Boll ${ }^{1}$, Ilana Rossi ${ }^{1}$, Silvana V. Amaral ${ }^{1}$, Ana Maria Leal-Zanchet ${ }^{1}$

$4 \quad{ }^{1}$ Instituto de Pesquisa de Planárias e Programa de Pós-Graduação em Biologia

5 Universidade do Vale do Rio dos Sinos - UNISINOS

6 São Leopoldo, RS, Brasil

7 Corresponding author: Ana Maria Leal-Zanchet, zanchet@unisinos.br

\section{Abstract}

Invasive species establish successfully in new habitats especially due to their ability to include new species in their diet and due to the freedom from natural enemies. However, native species may also adapt to the use of new elements in their ecosystem. The planarian Endeavouria septemlineata, first recorded in Hawaii, was later found in Brazil. Recently we found it in human-disturbed areas in southern Brazil and here we investigate its interactions with other invertebrates both in the field and in the laboratory. We observed the species in the field during collecting activities and hence maintained some specimens alive in small terraria in the laboratory, where we offered different invertebrate species as potential prey and also put them in contact with native land planarians in order to examine their interaction. Both in the field and in the laboratory, E. septemlineata showed a gregarious behavior and was found feeding on woodlice, millipedes, earwigs and gastropods. In the laboratory, specimens often did not attack live prey, but immediately approached dead specimens, indicating a scavenging behavior. In an experiment using the slug D. laeve and the woodlouse Atlantoscia floridana, there was a higher consumption of dead specimens of woodlice and slugs compared to live specimens, as well as a 
24 higher consumption of dead woodlice over dead slugs. Four native land planarians of the genus 25 Obama and one of the genus Paraba attacked and consumed E. septemlineata, which, after the 26 beginning of the attack, tried to escape by tumbling or using autotomy. As a scavenger, $E$.

27 septemlineata would have no impact on the populations of species used as food, but could

28 possibly exclude native scavengers by competition. On the other hand, its consumption by native

29 land planarians may control its spread and thus reduce its impact on the ecosystem.

30 Keywords: exotic prey, Geoplanidae, native predator, scavenger, invasive species 


\section{INTRODUCTION}

Most invasive species establish successfully in new habitats because of their ability to adapt their diets to include new species and due to the freedom from natural enemies (Colautti et al., 2004; Prior et al., 2014). However, as easily as an introduced species may adapt to a new environment, native species may adapt to a new element in their ecosystem. For example, native predators often adapt to exotic prey, controlling their populations (Carlsson, Sarnelle \& Strayer, 2009). Conversely, an invasive predator may benefit from the ineffective antipredator behavior of native species, thus increasing its chances of capturing prey (Sih et al., 2010).

Land planarians are important predators of other invertebrates in the soil fauna in tropical regions (Ogren, 1995; Sluys, 1999). Despite being sensitive to dehydration, high temperatures and luminosity, some species are able to adapt to human-disturbed environments and become invasive when colonizing areas outside their native range (Froehlich, 1955). The success of most invasive land planarians is attributed to their feeding habits, which gives them the ability to adapt their diet to include local invertebrate species, thus leading to a quick dispersal (Murchie, Moore \& Walter, 2003). Furthermore, the naïveté of native species to respond effectively to predation has been shown to increase the predation success of planarians (Fiore et al., 2004). The possibility of natural enemies to control invasive planarians is usually not taken into account because it is assumed that land planarians are top predators and therefore lack predators (Sluys, 1999).

Currently, several land planarians of the subfamily Rhynchodeminae that are native to Australasia are known as important invasive species (Winsor, Johns \& Barker, 2004; Justine, Thévenot \& Winsor, 2014; Álvarez-Presas et al., 2014; Justine et al., 2015). In Hawaii, Mead (1963) found that a rhynchodeminid planarian from tribe Caenoplanini, Endeavouria 
septemlineata (Hyman, 1939), is an effective predator on the introduced giant African snail. He

also observed the species feeding on earthworms and small insects. Later, E. semptemlineata was recorded for Brazil, although the impact of its invasion over native species was not studied (Carbayo, Pedroni \& Froehlich, 2008).

Recently, we found E. septemlineata in human-disturbed areas in southern Brazil. In order to understand its impact on the ecosystem and its effectiveness as an invasive species, we investigated its interactions with other invertebrates, both in the field and in the laboratory. Our predictions are that, as an effective invader, E. septemlineata would feed on a wide range of invertebrates. We also investigated whether or not native land planarians may use $E$. septemlineata as an alternative food source.

\section{MATERIAL AND METHODS}

We found specimens of E. semptelineata in gardens in Montenegro $\left(29^{\circ} 40^{\prime} \mathrm{S}, 51^{\circ} 28^{\prime} \mathrm{W}\right)$ and Campo Bom $\left(29^{\circ} 40^{\prime} \mathrm{S}, 51^{\circ} 3^{\prime} \mathrm{W}\right)$, and in the Porto Alegre Botanical Garden $\left(30^{\circ} 03^{\prime} \mathrm{S}\right.$, $\left.51^{\circ} 10^{\prime} \mathrm{W}\right)$, in Porto Alegre, Brazil. We documented occasional observations related to behavior in the field during collecting activities in the city of Montenegro and captured several specimens, taking them to the laboratory. We placed the planarians in plastic terraria with moist soil, leaves and $\log$ fragments at a temperature of $20^{\circ} \mathrm{C}$ and a relative air humidity of $90 \%$.

We killed nine specimens in hot water and fixed them in $10 \%$ buffered formalin. Later, we processed these specimens histologically (following Froehlich and Leal-Zanchet, 2003) for taxonomic identification through examination of the internal morphology and deposited them in the reference collection of Museu de Zoologia da Universidade do Vale do Rio dos Sinos, São Leopoldo, Rio Grande do Sul, Brazil. 
In the laboratory, we kept three groups of several specimens of E. septemlineata (between

10 and 30 individuals) alive in terraria with various invertebrate species as potential food items:

gastropods Deroceras laeve (O. F. Müller, 1774) and Bradybaena similaris (Férussac, 1821); isopods Atlantoscia floridana (Van Name, 1940), Benthana cairensis Skolowicz, Araujo \& Boelter, 2008, Porcellio scaber Latreille, 1804 and Armadillidium vulgare Latreille, 1804; termites Nasutitermes sp.; diplopods Rhinocricus sp.; and earthworms Eisenia andrei Bouché, 1972 and Metaphire schmardae (Horst 1883). We examined the terraria twice a week, searching for planarians feeding on the invertebrates.

Later, we performed two experiments of interaction. In the first one, we kept nine groups of five individuals of E. septemlineata alive in small terraria and offered two different invertebrates as food, the slug D. leave and the woodlouse A. floridana, in either of two states, alive or dead, totaling four treatments: live A. floridana, dead A. floridana, live D. laeve and dead D. laeve. We put five specimens of one of the treatments with each group of $E$. septemlineata for 24 hours. After that time, we recorded the number of items consumed and removed all food, putting the planarians in fast for 48 hours before offering a different food of random choice. We offered each treatment ten times throughout the nine groups and compared the mean number of consumed prey items in each treatment using a one-way analysis of variance with an a posteriori Tukey test.

In the second experiment, we tested the possibility of predation on E. septemlineata by native predators. Most known predators of land planarians in the Neotropical ecozone are other land planarians (Froehlich 1955), especially from the genera Obama and Paraba (Froehlich, 1955; Hauser and Maurmann, 1959). Therefore, we offered E. semptemlineata to native species of land planarians of these two genera, viz., Obama anthropophila Amaral, Leal-Zanchet \& 
101 Carbayo, 2015, O. carrierei (Graff, 1897), O. ficki (Amaral \& Leal-Zanchet, 2012), O. josefi

102 (Carbayo \& Leal-Zanchet, 2001), O. ladislavii (Graff, 1899), O. marmorata (Schultze \& Müller,

103 1857) and Paraba multicolor (Graff, 1899). We put one specimen of the native planarian and

104 one specimen of E. septemlineata in a moistened Petri dish under low diffuse light and examined

105 their interaction. We offered E. septemlineata fifteen times to each native land planarian species

106 and compared the rate of attacks of each species on E. septemlineata using a chi-square test.

107 The work was conducted under the collection permits and licenses granted by Instituto

108 Chico Mendes de Conservação da Biodiversidade (permit numbers 24357 and 26683).

109

110 RESULTS

111 Both in the field and in the laboratory, specimens of E. septemlineata showed a

112 gregarious behavior, constantly gathering in groups ranging from a few to tens of individuals

113 (Fig. 1A). Specimens were often found in the field feeding in groups on B. similaris (Fig. 1B), D.

114 leave, A. vulgare (Fig.1C), Rhinocricus sp. (Fig. 1D), and earwigs, or individually on A. vulgare

115 and Nasutitermes sp. (I. Rossi, personal observation).

116 In the laboratory, when in groups of 10 to 20 specimens, we found the planarians

117 consuming the woodlice A. vulgare and A. floridana individually and the land snail B. similaris

118 in groups. Despite being maintained in large groups with the invertebrates in the terraria for

119 several days, specimens of E. semptemlineata were rarely found eating.

120 In the first experiment of interaction, E. septemlineata showed higher consumption of

121 dead specimens over live specimens of both offered species. Also, there was a higher

122 consumption of dead $A$. floridana over dead D. laeve (ANOVA, $F=45.429, d f=3, p<0.001$;

123 Figure 2). 

carrierei, O. anthropophila (Fig. 3C) and Paraba multicolor (Fig. 3D) reacted to the encounter with E. septemlineata by capturing and consuming it. All species attacked and consumed $E$. septemlineata in more than $70 \%$ of the encounters, except $O$. marmorata, which only attacked in $53 \%$ of encounters $\left(\chi^{2}=16.337 ; d f=4 ; p=0.003\right)$.

At the beginning of the attack by the native planarians, individuals of E. septemlineata reacted by moving quickly away from the predator. The most frequent strategies to avoid

131 predation were tumbling or, if the posterior end was trapped, autotomy of the posterior end. The

132 planarian performed the tumbling behavior by lifting the posterior end and bending it forward 133 until touching the substrate ahead of the anterior end (Fig. 4).

135 showed a non-aggressive approaching behavior, often crawling either onto the dorsum or to the 136 side of the individual of the other species and entering a resting position in a way similar to the 137 one showed towards conspecific individuals. They only started an escape response after the 138 native planarian initiated the attack.

\section{DISCUSSION}

We observed specimens of E. septemlineata from southern Brazil feeding on a great

142 range of invertebrates, including mollusks and arthropods. In Hawaii, the invasive giant African

143 snail became a greatly available food source for E. septemlineata (Mead, 1963). This led to a

144 boost in the population and, consequently, the predation impact over native land snails increased.

145 According to Mead (1963), the low density of native land snails on the island makes them

146 unlikely to be the main prey of the planarian. Our results corroborate this hypothesis of a diet 
147 including more than only gastropods. Such feeding habits, including both gastropods and

148 arthropods, have been reported for other species of Caenoplanini, such as Caenoplana coerulea

149 and Parakontikia ventrolineata (Winsor, Johns \& Barker, 2004; Breugelmans et al. 2012), the

150 latter also known to feed in groups (Barker, 1989).

151 Despite the fact that we find groups of E. septemlineata feeding on several invertebrates

152 in the field, the specimens rarely eat live prey in the laboratory, frequently ignoring them. Mead

153 (1963) reports feeding observations in the laboratory that included the capture of live snails, but

154 gives no details about the conditions in which the planarians were maintained. Carbayo, Pedroni

$155 \&$ Froehlich (2008) reported that, under laboratory conditions, E. septemlineata accepted snails

156 and smashed slugs, but they also did not present details about the observations. Our results

157 contrast with those observations, as there was higher consumption of dead woodlice in relation to

158 dead or live slugs, as well as no statistical differences among the consumption of live or dead

159 slugs and live woodlice.

160 In experiments with native species of Microplana in the United Kingdom, McDonald and

161 Jones (2007) found that the planarians eat live prey less frequently in the laboratory than in the

162 field, although they accepted dead animals rather well. This may indicate that those species are

163 more scavengers than predators. A species closely related to E. septemlineata that shows a

164 similar gregarious behavior is $P$. ventrolineata. It has been reported to attack live prey actively in

165 the field (Barker, 1989), but recent observations also indicate a scavenging behavior (Justine,

166 Thévenot \& Winsor, 2014). Our observations suggest that E. semptemlineata is mainly a

167 scavenger.

168 As an obligate or facultative scavenger, E. septemlineata would have little effect on the

169 population of most invertebrates it consumes as food, since it would not decrease significantly 
170 the population size of those species. Nevertheless, it would decrease the amount of dead material

171 available for native scavengers, leading to competition and, if having advantage over the

172 resources, the invasive species may dislodge a native scavenger or force it to change its diet

173 (Wilson and Wolkovich, 2011).

174 Nevertheless, despite the considerably wide occurrence of E. septemlineata in Brazil

175 (Carbayo, Pedroni \& Froehlich, 2008), its impact over the populations of native species may be

176 under control due to its predation by native land planarians. In our study, which was restricted to

177 southern Brazil, five native land planarians fed on E. septemlineata. When considering the range

178 of distribution of this invasive species, it is likely that more predator species exist.

179 The control of invasive land planarians by predators has always seemed unlikely to

180 succeed, as few natural predators are known (Justine et al., 2014). Besides beetles (Gibson,

181 Cosens \& Buchanan, 1997) and one snail species (Lemos, Canello \& Leal-Zanchet, 2012), no

182 other organisms have been reported to feed on introduced land planarians prior to the present

183 work. Vertebrates usually do not accept land planarians as food as they seem to find them

184 unpalatable (Ducey et al., 1999), although some birds may readily eat flatworms (Hugh Jones,

185 personal communication).

186 Europe is the continent most affected by invasive land planarians (Álvarez-Presas et al.

187 2014; Justine, Thévenot \& Winsor, 2014), but it also has a very small number of native species.

188 Thus, native European animals are unlikely to predate land planarians, since land planarians

189 compose a rare group on this continent and therefore are not available as a significant food

190 resource. On the other hand, South America has a high richness of land planarians and effective

191 predators are very likely to exist. One such predator, the land snail Rectartemon depressus,

192 which consumes various native species of land flatworms, has been identified recently (Lemos, 
193 Canello \& Leal-Zanchet, 2012). The consumption of the invasive E. septemlineata by native land

194 planarians, including species common to urban environments, may be an important factor in

195 controlling the dispersal of introduced land planarians in South America.

196 The inclusion of exotic prey in the diet of a native predator, sometimes even leading it to

197 switch from a native to an exotic species as a main food source, is not uncommon (Carlsson,

198 Sarnelle \& Strayer, 2009), although it seems to vary considerably depending on the type of

199 ecosystem and the trophic level (Prior et al., 2014). Obama anthropophila, O. carrierei and $O$.

200 josefi seem to have other native land planarians as their main prey (P. Boll, personal observation)

201 and thus may recognize E. septemlineata as a suitable species to replace native prey. The

202 consequences of such interaction over the populations of both predator and prey depend on the

203 responsive capacities of both species, including rapid adaptive change of individuals by learning

204 or changes in morphology and behavior within a population due to natural selection (Carlsson,

205 Sarnelle \& Strayer, 2009).

206 Our results suggest that, as primarily a scavenger, E. septemlineata may not have

207 significant effects on native species on which it feeds, and its spread may be controlled by native

208 predators. However, it is possible that its presence significantly affects the trophic web structure

209 by dislodging native scavengers or altering the predation pressure on native preys by native

210 predators.

211

212 ACKNOWLEDGMENTS

213 We thank Elisa von Groll, João Braccini, Lucas Schvambach, Márcio Sasamori and Victor Sawa

214 for helping in the capture of land planarians; Ignacio Agudo, Marie Bartz and Patrícia Rodrigues

215 for the help in identifying invertebrate species. We acknowledge MSc. Edward Benya for the 
216 English review of the text. Dr. Hugh Jones, Dr. Leigh Winsor and an anonymous reviewer are

217 acknowledged for their constructive comments on an earlier draft of the paper.

218

219

220

REFERENCES

221 Álvarez-Presas M., Mateos E., Tudó À., Jones H., Riutort M. 2014. Diversity of introduced 222 terrestrial flatworms in the Iberian Peninsula: a cautionary tale. PeerJ 2:e430.

223 Barker GM. 1989. Flatworm predation of terrestrial molluscs in New Zealand, and a brief review 224 of previous records. New Zealand Entomologist 12:75-79.

225 Breugelmans K., Quintana Cardona J., Artois T., Jordaens K., Backeljau T. 2012. First report of 226 the exotic blue land planarian, Caenoplana coerulea (Platyhelminthes, Geoplanidae), on 227 Menorca (Balearic Islands, Spain). ZooKeys 199:91-105.

228 Carbayo F., Pedroni J., Froehlich EM. 2008. Colonization and extinction of land planarians 229 (Platyhelminthes, Tricladida) in a Brazilian Atlantic Forest regrowth remnant. Biological $230 \quad$ Invasions 10:1131-1134.

231 Carlsson NO., Sarnelle O., Strayer DL. 2009. Native predators and exotic prey - an acquired 232 taste? Frontiers in Ecology and the Environment 7:525-532.

233 Colautti RI., Ricciardi A., Grigorovich IA., MacIsaac HJ. 2004. Is invasion success explained by 234 the enemy release hypothesis? Ecology Letters 7:721-733.

235 Ducey PK., Messere M., Lapoint K., Noce S. 1999. Lumbricid prey and potential herpetofaunal 236 predators of the invading terrestrial flatworm Bipalium adventitium (Turbellaria: Tricladida:

237 Terricola). The American Midland Naturalist 141:305-314. 
238 Fiore C., Tull JL., Zehner S., Ducey PK. 2004. Tracking and predation on earthworms by the 239 invasive terrestrial planarian Bipalium adventitium (Tricladida, Platyhelminthes).

240 Behavioural Processes 67:327-334.

241 Froehlich CG. 1955. On the biology of land planarians. Boletim da Faculdade de Filosofia, 242 Ciências e Letras da Universidade de São Paulo, Série Zoologia 20:263-271.

243 Froehlich EM., Leal-Zanchet AM. 2003. A new species of terrestrial planarian of the genus 244 Notogynaphallia Ogren \& Kawakatsu (Platyhelminthes, Tricladida, Terricola) from south 245 Brazil and some comments on the genus. Revista Brasileira de Zoologia 20:745-753.

246 Gibson PH., Cosens D., Buchanan K. 1997. A chance field observation and pilot laboratory 247 studies of predation of the New Zealand flatworm by the larvae and adults of carabid and $248 \quad$ staphylinid beetles. Annals of Applied Biology 130:581-585.

249 Hauser JH., Maurmann E. 1959. Studien über die Bewegungen des “Genus Geoplana.” Pesquisas $250 \quad 3: 631-646$.

251 Hyman LH. 1939. Land Planarians from the Hawaiian Islands. Archives de Zoologie 252 Expérimentale et Genérale 80:116-124.

253 Justine J-L., Winsor L., Gey D., Gros P., Thévenot J. 2014. The invasive New Guinea flatworm 254 Platydemus manokwari in France, the first record for Europe: time for action is now. PeerJ $255 \quad 2: \mathrm{e} 297$.

256 Justine J-L., Winsor L., Barrière P., Fanai C., Gey D., Han AWK., La Quay-Velázquez G., Lee 257 BPY-H., Lefevre J-M., Meyer J-Y., Philippart D., Robinson DG., Thévenot J., Tsatsia F. 258 2015. The invasive land planarian Platydemus manokwari (Platyhelminthes, Geoplanidae): 259 records from six new localities, including the first in the USA. PeerJ 3:e1037. 
260 Justine J-L., Thévenot J., Winsor L. 2014. Les sept plathelminthes invasifs introduits en France. 261 Phytoma 674:28-32.

262 Lemos VS., Canello R., Leal-Zanchet AM. 2012. Carnivore mollusks as natural enemies of 263 invasive land flatworms: Mollusks as natural enemies of flatworms. Annals of Applied 264 Biology 161:127-131.

265 McDonald JC., Jones HD. 2007. Abundance, reproduction, and feeding of three species of British 266 terrestrial planarians: Observations over 4 years. Journal of Natural History 41:293-312.

267 Mead AR. 1963. A flatworm predator of the giant African snail Achatina fulica in Hawaii. $268 \quad$ Malacologia 1:305-311.

269 Murchie AK., Moore JP., Walters KFA., Blackshaw RP. 2003. Invasion of agricultural land by 270 the earthworm predator, Arthurdendyus triangulatus (Dendy): The 7th international 271 symposium on earthworm ecology $\cdot$ Cardiff $\cdot$ Wales $\cdot$ 2002. Pedobiologia 47:920-923.

272 Ogren RE. 1995. Predation behaviour of land planarians. Hydrobiologia 305:105-111.

273 Prior KM., Powell THQ., Joseph AL., Hellmann JJ. 2014. Insights from community ecology into 274 the role of enemy release in causing invasion success: the importance of native enemy 275 effects. Biological Invasions 17:1283-1297.

276 Sih A., Bolnick DI., Luttbeg B., Orrock JL., Peacor SD., Pintor LM., Preisser E., Rehage JS., 277 Vonesh JR. 2010. Predator-prey naïveté, antipredator behavior, and the ecology of predator 278 invasions. Oikos 119:610-621.

279 Sluys R. 1999. Global diversity of land planarians (Platyhelminthes, Tricladida, Terricola): a new 280 indicator-taxon in biodiversity and conservation studies. Biodiversity \& Conservation $281 \quad 8: 1663-1681$. 
282 Sugiura S. 2009. Seasonal fluctuation of invasive flatworm predation pressure on land snails:

283 Implications for the range expansion and impacts of invasive species. Biological

284 Conservation 142:3013-3019.

285 Sugiura S. 2010. Prey preference and gregarious attacks by the invasive flatworm Platydemus 286 manokwari. Biological Invasions 12:1499-1507.

287 Wilson EE., Wolkovich EM. 2011. Scavenging: how carnivores and carrion structure 288 communities. Trends in Ecology \& Evolution 26:129-135.

289 Winsor L., Johns PM., Barker GM. 2004. Terrestrial planarians (Platyhelminthes: Tricladida: 290 Terricola) predaceous on terrestrial gastropods. In: Barker GM ed. Natural enemies of 291 terrestrial molluscs. Wallingford: CABI, 227-278. 


\section{1}

Figure 1 Behavior of Endeavouria septemlineata

Figure 1 Behavior of Endeavouria septemlineata: (A) Specimens gathering in a group of many individuals in the field; Specimens feeding on (B) the snail Bradybaena similaris, (C) the woodlouse Armadillidium vulgare and (D) the millipede Rhinocricus sp. in the field; (E) A single specimen feeding on the woodlouse Atlantoscia floridana in the laboratory.

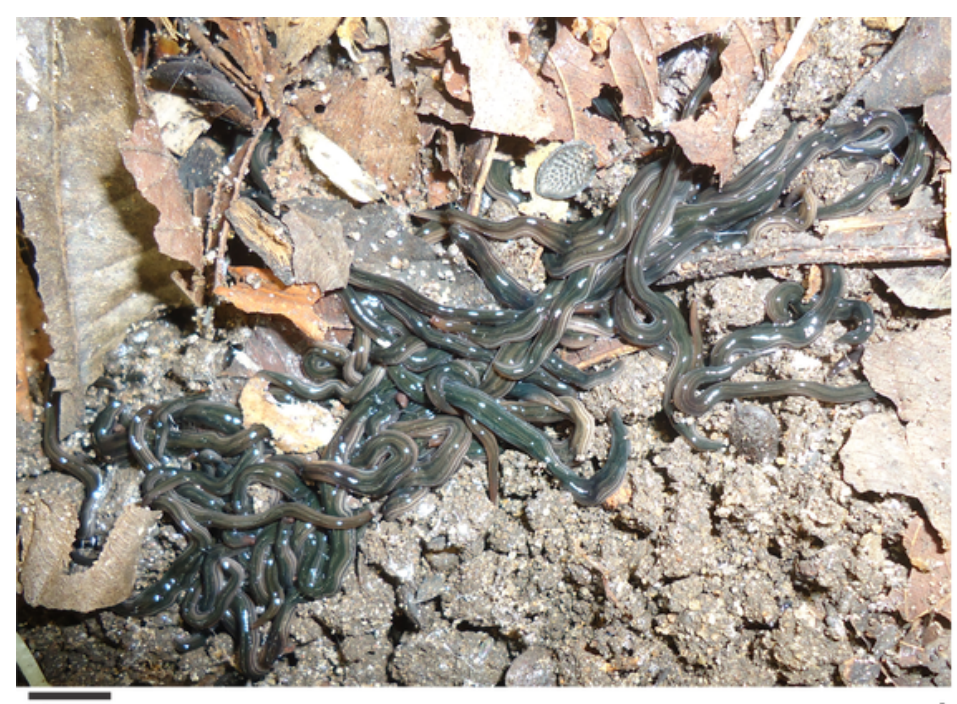

$10 \mathrm{~mm}$

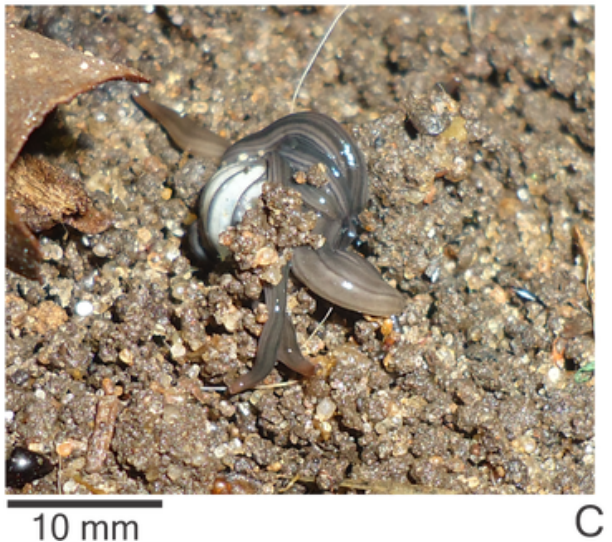

$$
\text { A }
$$

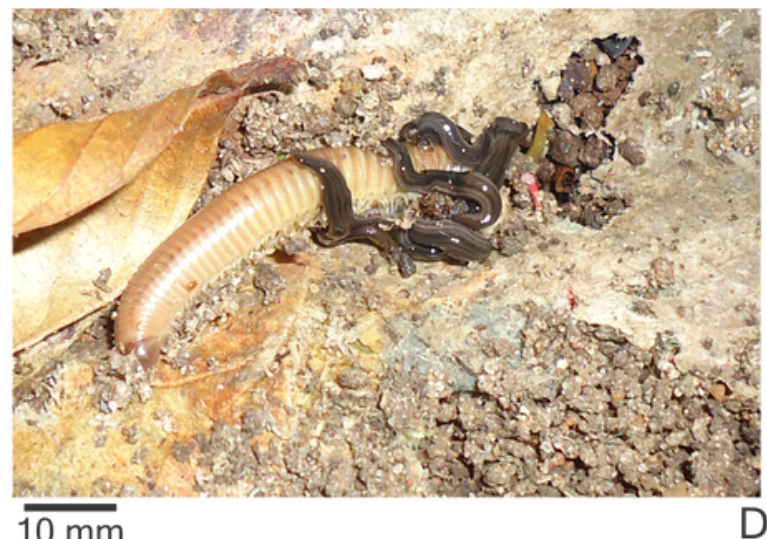

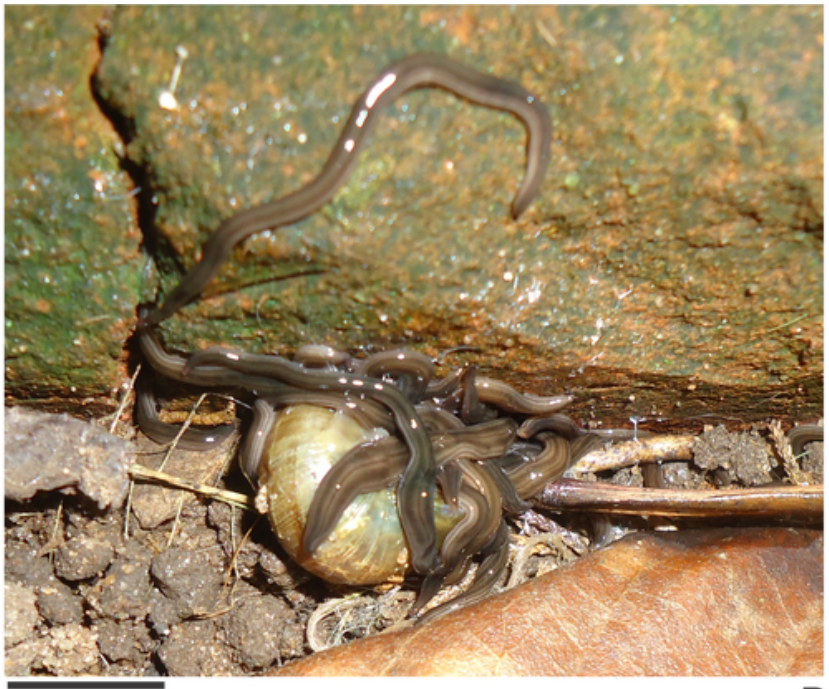

B

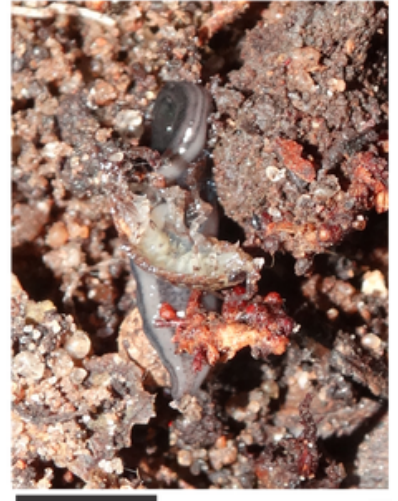

$10 \mathrm{~mm}$ 
2

Figure 2 Mean number of food items consumed by five specimens of Endeavouria septemlineata in 24 hours.

Figure 2 Mean number of food items consumed by five specimens of Endeavouria septemlineata in 24 hours. LAF = live Atlantoscia floridana; DAF = dead $A$. floridana; LDL = live Deroceras laeve; $\mathrm{DDL}=$ dead $D$. laeve. Different letters indicate significant differences.

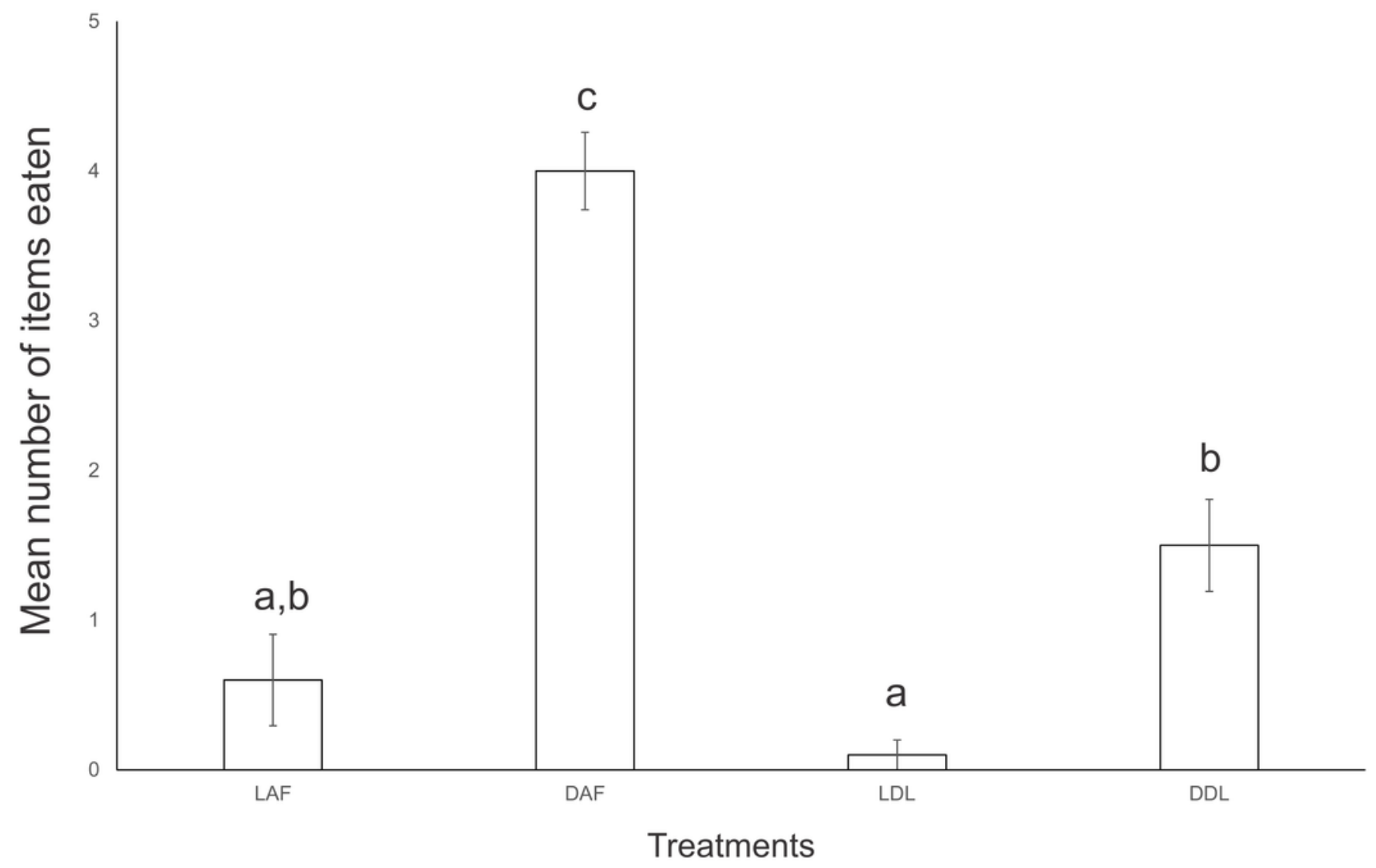




\section{3}

Figure 3 Native land planarians consuming Endeavouria septemlineata in experiments in the laboratory

Figure 3 Native land planarians consuming Endeavouria septemlineata in experiments in the laboratory: (A) Obama josefi in ventral view; (B) Obama marmorata in ventral view; (C) Obama anthropophila in dorsal view; and (D) Paraba multicolor in dorsal view. Arrows indicate the pharynx of the predators; double arrows show parts of the body of a preyed specimen of $E$. septemlineata in the intestine.
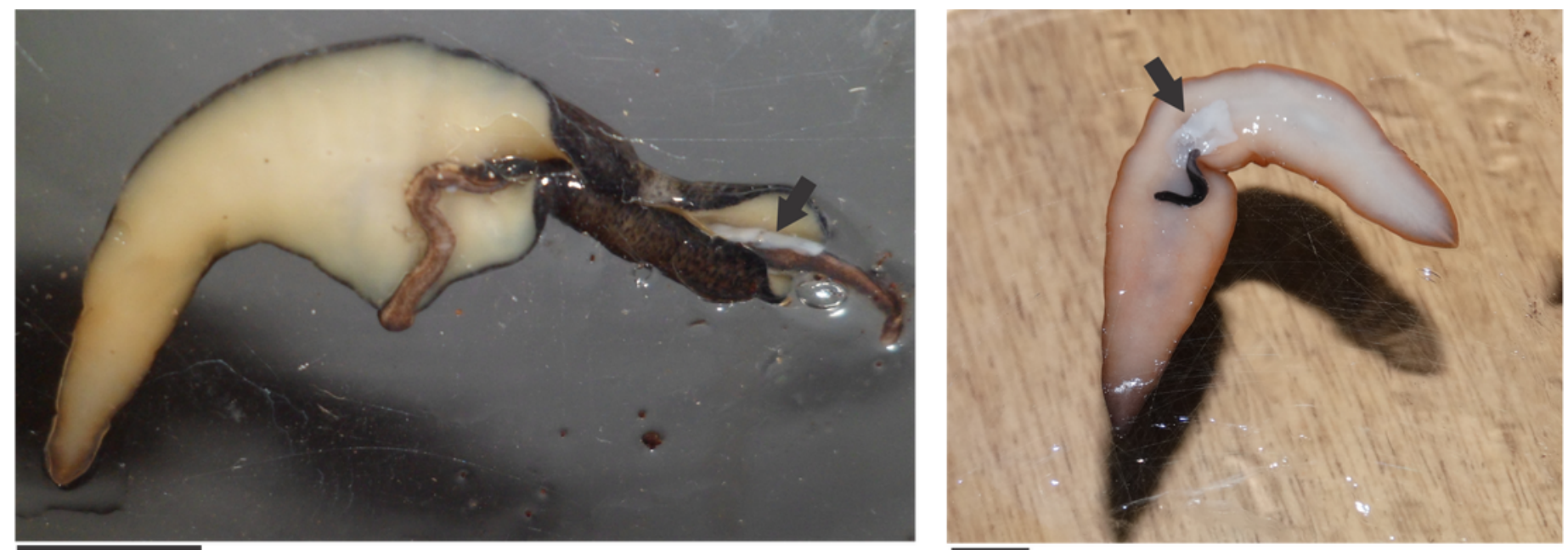

$10 \mathrm{~mm}$

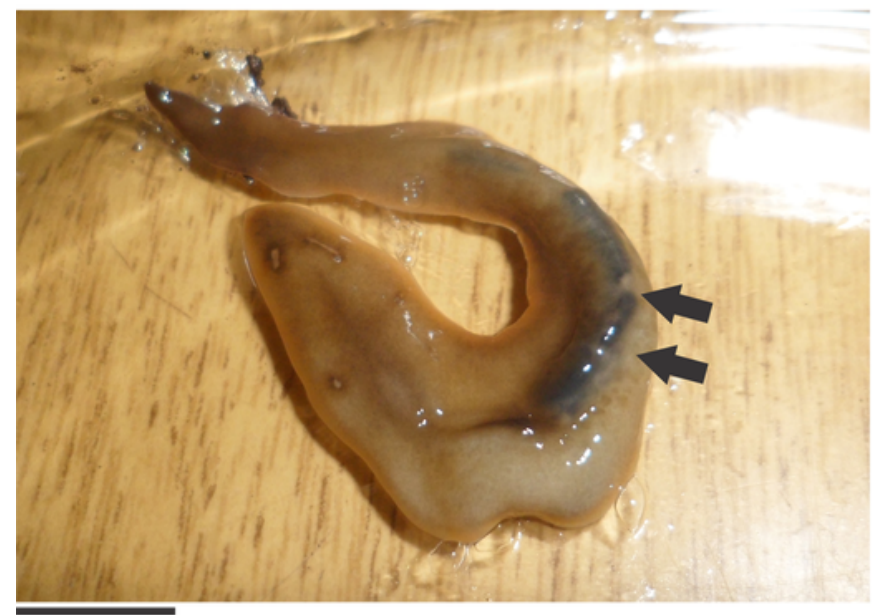

$10 \mathrm{~mm}$
A $\overline{10 \mathrm{~mm}}$

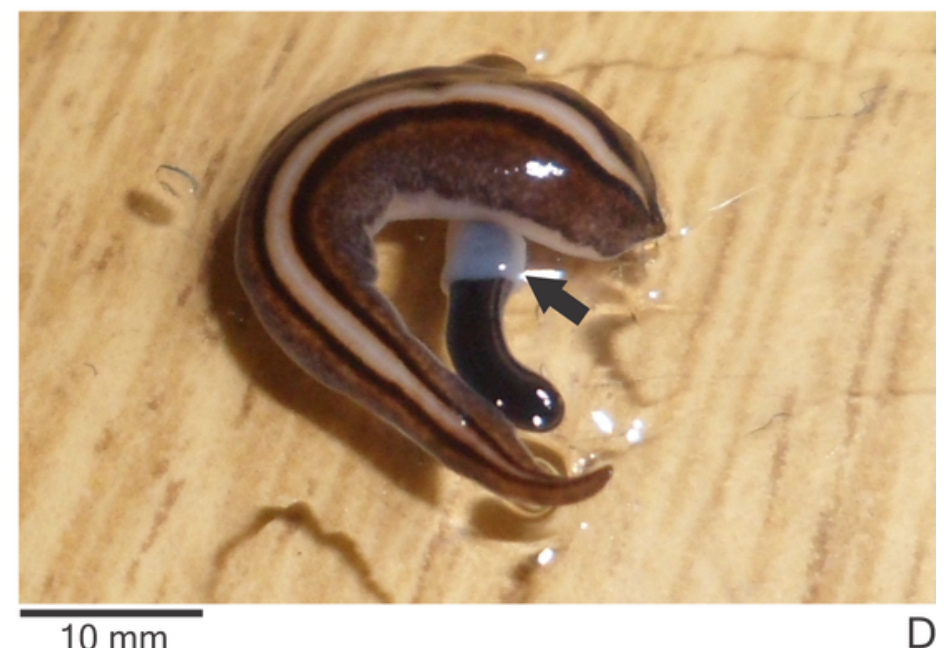


4

Figure 4 Tumbling behavior of Endeavouria septemlineata

Figure 4 Tumbling behavior of Endeavouria septemlineata: (A) initial position; (B) posterior end lifted and bent forward; $(C)$ posterior end touching the substrate ahead of the anterior end; (D) anterior end lifted; (E) final position. Arrows show head in initial and final positions.

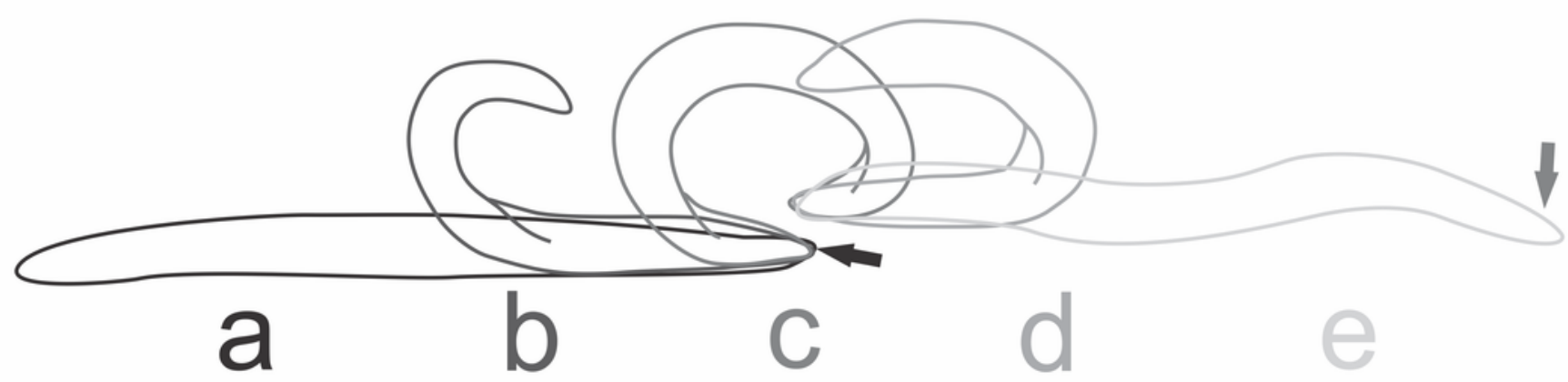

